\title{
CONTEXT MATTERS: \\ PAUL'S USE OF LEVITICUS 18:5 IN GALATIANS 3:12
}

\author{
Joel Willitts
}

\begin{abstract}
Summary
Galatians 3:10-14 is arguably one of the most difficult passages in all of the Pauline letters. The varied interpretations can be organised into three approaches that currently dominate the exegetical landscape: law/gospel antithesis, apocalyptic fulfilment and redemptive historical. All three approaches, however, have overlooked the reuse of the Leviticus 18:5 clause, 'the one who does these things will live by them' (Gal. 3:12b), in later Jewish interpretative tradition. This interpretative tradition may be a useful source in our attempt to grasp Paul's argument in Galatians 3:10-14. This essay sets out to: (1) investigate the Leviticus 18:5 clause in the Jewish interpretative tradition, and (2) offer a fresh reading of Galatians 3:10-14 within a redemptive historical/exile-restoration framework.
\end{abstract}

\section{Introduction}

The citation from Leviticus $18: 5$ is the third in a string of three quotations $^{1}$ in Galatians 3:10-12. The function of Leviticus 18:5 in the argument of chapter 3 is hotly debated as is the entire section in which it appears. About the only issue on which scholars have found consensus is the fact that the text is one of the most difficult in the

1 Deut. 27:26 (28:58, 30:10), Hab. 2:4 and Lev. 18:5. While it is acknowledged that in this passage Paul only uses a 'quotation formula' for the first of the three quotations, C.D. Stanley's caution (Paul and the Language of Scripture: Citation Technique in the Pauline Epistles and Contemporary Literature [Cambridge: CUP, 1992], 66) is helpful, '... Paul can be quite creative in the way he incorporates citations into his own literary compositions'. Moreover, Stanley believes Lev. 18:5 is a quotation because of 'the lack of grammatical concord between the citation and its new context' (Stanley, Paul, 66). 
Pauline corpus. ${ }^{2}$ While there are almost as many interpretations of Galatians $3: 10-12$ as interpreters, three approaches dominate the current exegetical landscape; they are the law/gospel antithesis approach, the apocalyptic fulfilment approach, and the redemptive historical approach. I am not attempting in this article to argue for the superiority of one approach over another. Of the three, the most persuasive, to my mind, is the redemptive historical approach, although it is not without its own difficulties. Nevertheless, all three approaches have overlooked what could be a key point in the interpretation of Galatians 3:12 and this article sets out to both highlight and explore this omission as well as offer a fresh reading of Galatians 3:12 in light of it. This task will be accomplish by (1) briefly reviewing the three dominant interpretative approaches, (2) tracing Leviticus 18:5 in later Jewish interpretation in and outside the canon, and (3) offering an exegesis of Galatians 3:10-14 in light of the later Jewish tradition.

\section{Review of Interpretative Approaches}

The Law/Gospel Antithesis. R. Longenecker provides a contemporary example of this approach to Galatians 3:10-12 when he states, 'Paul sets up a sharp antithesis ... righteousness is to be associated with faith alone; curse is the result of trying to observe the law in order to gain righteousness.' ${ }^{3}$ On verse 12 Longenecker further writes, '[Paul's]

2 J.D.G. Dunn, A Commentary on the Epistle to the Galatians (Black's New Testament Commentaries; London: A \& C Black, 1993), 83, notes that this paragraph is 'one of the most difficult to follow that Paul ever dictated'.

3 R.N. Longenecker, Galatians (WBC 41; Dallas: Word Books, 1990), 119, also

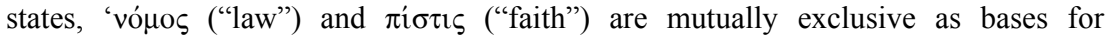
righteousness'. Cf. also M. Luther, Galatians (Crossway Classic Commentaries; Wheaton: Crossway, 1998); J. Calvin, Commentaries on the Epistles of Paul to the Galatians and Ephesians (Edinburgh: T \& T Clark, 1854); E. Burton, A Critical and Exegetical Commentary on the Epistle to the Galatians (ICC; Edinburgh: T \& T Clark, 1921); J.B. Lightfoot, Saint Paul's Epistle to the Galatians: A Revised Text with Introduction, Notes, and Dissertations (London: Macmillan, 1921); F.F. Bruce, The Epistle to the Galatians: A Commentary on the Greek Text (NIGTC; Grand Rapids: Eerdmans, 1982); R. Fung, The Epistle to the Galatians (NICNT; Grand Rapids: Eerdmans, 1988); J. Becker, 'Die Briefe an die Galater', in Die Briefe an die Galater, Epheser, Philipper, Kolosser, Thessalonicher und Philemon (Göttingen: Vandenhoeck \& Ruprecht, 1976), 1-85; F.J. Matera, Galatians (Sacra Pagina 9; Collegeville, MN: Liturgical, 1992); G.W. Hansen, Galatians (IVP New Testament Commentary Series; Downers Grove: InterVarsity, 1994); and B. Witherington, Grace in Galatia: A Commentary on St. Paul's Letter to the Galatians (Grand Rapids: Eerdmans, 1998); S. Kim, Paul and the New Perspective: Second Thoughts on the Origin of Paul's Gospel 
point in quoting Leviticus 18:5 is obvious: the law has to do with "doing" and "living by its prescriptions" and not with faith'. ${ }^{4}$ As is evident from these quotations, this approach drives a wedge between the law and faith. In this view typically, the law is thought to bring a curse $(3: 10)$ because no one can perfectly do all that is required by the law. Because God demands sinless obedience, and no one can obey sinlessly, everyone is under a curse. One cannot earn salvation by 'doing the law', because salvation can only come through 'faith'. Thus there is an emphasis on 'faith in Christ' over against the 'doing of the law'.

The Apocalyptic Fulfilment Approach. J.L. Martyn has argued for an apocalyptic approach to the reading of Galatians. He rightly desires to be considered in his own right not only because of his theological influence on the study of Galatians, but also because scholars have hailed his commentary one of the best on the New Testament in the 20th century. ${ }^{5}$ In his interpretation of Galatians 3:11-12 he believes Paul has employed a modified literary form called 'Textual Contradiction'. With this form Paul, according to Martyn, has shown that the two concepts (Hab. 2:4 and Lev. 18:5), although both drawn from the same source (i.e. the Scripture), are fundamentally in contradiction to one another. In this regard Martyn asserts that although the fundamental premise of the literary form of 'Textual Contradiction' is that 'the law (or Scripture) cannot ultimately be in conflict with itself, Paul does not attempt to resolve the contradiction between his text from Habakkuk and the Teachers' text from Leviticus'. ${ }^{6}$ Martyn argues that Paul replaced the fundamental assumption that 'the two texts have their origin in a monolith that is larger and more fundamental than either of them' with the fundamental of faith. ${ }^{7}$ Faith now is the 'benchmark from which all else must be judged .... ${ }^{8}$ Thus Paul has measured the law by the benchmark of faith

(Grand Rapids: Eerdmans, 2002). Surprisingly, even H.D. Betz, Galatians (Hermeneia; Philadelphia: Fortress, 1979) and E.P. Sanders, Paul, the Law, and the Jewish People (Minneapolis: Fortress, 1983) fall under the law/gospel antithesis approach of interpretation, though not agreeing with the assumption that Paul believed the law demanded sinless perfection.

4 Longenecker, Galatians, 120.

5 Cf. G. Stanton, 'Review of Galatians: A New Translation with Introduction and Commentary by J. Louis Martyn', JTS 51 (2000) 264.

6 J.L. Martyn, Galatians (AB 33A; New York: Doubleday, 1997), 332-33.

7 Martyn, Galatians, 332.

8 Martyn, Galatians, 332. 
and found it, as it is summed up in Leviticus 18:5, to be wanting. Paul's assertion in Galatians 3:12 (with the Lev. 18:5 citation) is that the 'law' (= Israelite religious system) is in contradiction to 'faith' (= God's apocalyptic revelation). For Martyn it is not the inability or ability of the people to keep the law that is at issue here, but it is the irrelevance of the law in light of God's apocalyptic intervention in Christ. ${ }^{9}$

The Redemptive Historical Approach. D. Garlington represents the redemptive historical approach when he suggests that Galatians 3:1112 should be read in a 'historical' manner. Paul's argument 'is not a topical discussion of faith and works, but an epochal delineation of the

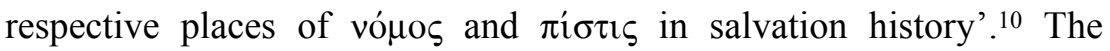
contrast is between the two eras of God's dealing with his people within salvation history. S.J. Hafemann has summarised this approach by observing, "the rubrics of "Law" or "works of the Law" ... and "Gospel" or "faith" are thus often being used to summarize what is also commonly called the old and new covenants, old and new ages, or creation and new creation'. ${ }^{11}$ In addition, J.M. Scott and N.T. Wright have independently suggested a redemptive historical approach that utilises the Sin-Exile-Restoration motif. ${ }^{12}$

While each of these approaches possess weaknesses, it is still surprising that in their exegesis of Galatians 3:12, none of the three

9 R. Bultmann, Theology of the New Testament, Vol. 1 (trans. K. Grobel; London: SCM, 1952), 263, arrived at the same conclusion, although for different reasons, He states, '... he [Paul] says not only that man can not achieve salvation by works of the Law, but also that he is not even intended to do so.'

10 D. Garlington, 'Role Reversal and Paul's Use of Scripture in Galatians 3.10-13', JSNT 65 (1997) 108. Cf. also R.B. Hays, 'The Letter to the Galatians', in NIB, ed. L.E. Keck, 11 (Nashville: Abingdon, 2000), 183-348); S.J. Hafemann, 'Paul and the Exile of Israel in Galatians 3-4', in Exile: Old Testament, Jewish and Christian Conceptions, ed. J.M. Scott (Supplements to JSJ 56; Leiden: Brill, 1997), 329-71; R. Hall, 'Arguing Like an Apocalypse: Galatians and an Ancient Topos Outside the Greco-Roman Rhetorical Tradition', NTS 42 (1996) 434-53; C.H. Cosgrove, The Cross and The Spirit: A Study in the Argument and Theology of Galatians (Macon, GA: Mercer University, 1988); Dunn, Galatians; and J. Wisdom, Blessing for the Nations and the Curse of the Law: Paul's Citation of Genesis and Deuteronomy in Gal 3.8-10 (WUNT 133; Tübingen: Mohr Siebeck, 2001) who fall under the rubric of a redemptive historical interpretative approach.

11 S.J. Hafemann, The God of Promise and the Life of Faith: Understanding the Heart of the Bible (Wheaton: Crossway Books, 2001), 245.

12 J.M. Scott, 'For as Many as Are of Works of the Law Are under a Curse (Galatians 3:10)', in Paul and the Scriptures of Israel, ed. C.A. Evans and J.A. Sanders (JSNTSup 83; Sheffield: JSOT, 1993), 187-221; and N.T. Wright, The Climax of the Covenant: Christ and the Law in Pauline Theology (Minneapolis: Fortress, 1991), 137-56. 
approaches seriously considers the possibility that Paul reads Leviticus 18:5 against a broader interpretative backdrop than its immediate one in the Pentateuch. This is striking because the clause reappears, almost verbatim, in Ezekiel and Nehemiah and in the Dead Sea Scrolls. ${ }^{13}$ It is quite possible, then, that Paul read Leviticus 18:5 through the lens of later interpretative tradition.

This reuse of scripture in the Hebrew Bible is well known and has been termed 'inner-biblical exegesis'. ${ }^{14} \mathrm{M}$. Fishbane has gathered a host of evidence showing how earlier scriptural traditions were later adapted and reapplied to new contexts both inside and outside the Hebrew canon. ${ }^{15} \mathrm{He}$ distinguishes between traditum and the traditio, by which he means the original context of the tradition and the process by which that tradition is passed on. ${ }^{16}$ He notes that the process 'starts with the received Scripture and moves forward to the interpretations based on it' with a concern not 'to reproduce the traditum, but to reactualise it in a new setting and a new way'. ${ }^{17}$ It is quite probable then, that the contemporary circumstances surrounding the formulation

13 I can find no interpreter who understands Paul's use of Lev. 18:5 as idiosyncratic or atomistic. In fact all the interpreters of which I am presently aware take Paul to be drawing on the context of Lev. in one way or another. However, in the OT books of Ezek. $(20: 11 ; 13 ; 21)$ and Neh. $(9: 29-2$ Esd. 19:29 in LXX) and in the Damascus Document of the DSS (CD III, 16) the clause from Lev. 18:5 is reused and its significance is expanded. Some commentators (Garlington, Role, 1997; T.R. Schreiner, The Law and Its Fulfillment [Grand Rapids: Baker, 1993]) note the occurrences in Ezek. and Neh. but none have investigated the clause in later scriptural tradition and its significance for Paul's argument in Gal. 3:10-12.

14 The questions related to the text and text-form from which Paul draws his quotation are difficult. In light of the evidence of textual diversity in the 1st century, it is legitimate to ask simply, what 'text' was Paul quoting from? It is not possible in this short paper to discuss this issue in any great detail. I assume in this paper that Paul is quoting a text similar, if not identical, to the LXX. For further discussion on the issue of text and text-form as well as the difficult issue of identifying the reuse of biblical texts in ancient literature see E. Tov, Textual Criticism of the Hebrew Bible (2nd rev. ed.; Minneapolis and Assen: Fortress and Van Gorcum, 2001); E. Ulrich, 'The Dead Sea Scrolls and the Biblical Text', in The Dead Sea Scrolls after Fifty Years: A Comprehensive Assessment, Vol. 1, ed. P.W. Flint and J.C. VanderKam (Leiden: Brill, 1998), 79-100; R.B. Hays, Echoes of Scripture in the Letters of Paul (New Haven: Yale University, 1989); T.H. Lim, Holy Scripture in the Qumran Commentaries and Pauline Letters (Oxford: Clarendon, 1997); Stanley, Paul; and J.R. Wagner, Heralds of the Good News: Isaiah and Paul 'In Concert' in the Letter to the Romans (NovTSup 101; Leiden: Brill, 2002).

15 M.A. Fishbane, Biblical Interpretation in Ancient Israel (Oxford: Clarendon, 1984); cf. also the recent work by B.D. Sommer, A Prophet Reads Scripture: Allusion in Isaiah 40-66 (Stanford, CA: Stanford University, 1998).

16 Fishbane, Biblical, 6.

17 Fishbane, Biblical, 416-17; cf. also Bryan, Jesus, 7. 
of Ezekiel and Nehemiah on the one hand, and the Qumran community on the other lead them to adapt Leviticus 18:5 in light of their historical contexts. The evidence of inner-biblical exegesis in later Jewish tradition, admittedly, cannot prove that Paul read Leviticus 18:5 in the same way Ezekiel, Nehemiah or the Dead Sea Scroll community have. However, it seems reasonable to propose that Paul's use of the Leviticus 18:5 clause in Galatians 3:12 is accordant with this later interpretative tradition and, hence, we are justified in the investigation of the possibility that Paul might have read Leviticus 18:5 in concert with or even through the lens of the later Jewish tradition. ${ }^{18}$

Furthermore, hinting at the thesis of this article, when Leviticus 18:5 is read against the backdrop of its later Jewish interpretation, the clause takes on an expanded eschatological significance. Moreover, in the argument of Galatians 3:10-12 it seems probable that Paul reflects this expanded significance in his own reuse of Leviticus 18:5. In this way, Paul becomes another in the line of Jewish Scriptural interpreters who reactualise in a similar manner this earlier tradition in a new historical situation.

\section{Leviticus 18:5 in Jewish Scripture and Qumran}

\subsection{Leviticus 18:5 in the Pentateuch}

Leviticus 18:5 falls within the Pentateuch in a section that has been labelled 'the holiness code'. Chapters 17-27 contain a series of laws

18 Literary evidence has shown that the lectionaries used in the synagogue associated with the triennial cycle reveal the common Jewish practice of reading Torah (seder) in light of the Prophets (haftarah) (cf. J. Mann, The Bible as Read and Preached in the Old Synagogue ... Vol. 2, The Palestinian Triennial Cycle: Leviticus and Numbers to Seder 106 [Cincinnati, OH: Hebrew Union College, 1966]). Mann, after studying the Yelamedenu homilies, argued that synagogue sermons were structured around the haftarah and so "the real connection of the particular Y[elamedenu] homily with the corresponding text from the Pentateuch, constituting the S[eder] of the Sabbath, is throughout to be looked for in the Prophetical lesson accompanying this S[eder]' (The Bible as Read, 1.24). Though the dating of this triennial cycle is difficult to establish, it can be reasonably assumed that the practice of reading the Torah through the Prophets is ancient, especially in light of S. Zeitlin's conclusion (in 'Midrah: A Historical Study', JQR 44 [1953] 28-29) that the haftaroth and the sedarim were connected before the fall of Jerusalem in AD 70. In light of this evidence, it seems probable that Paul would have naturally read Torah passages through the lens of the Prophets. See K. Jobes, 'Jerusalem, Our Mother: Metalepsis and Intertextuality in Galatians 4:21-31', WTJ 55 (1993) 318, who argues for a similar phenomenon in Paul. 
that Garlington has rightly summarised with the clause: 'maintaining the covenant with a holy God'. ${ }^{19}$ This section covers a wider variety of topics, but 'the centre of gravity is that of the preserving the integrity of the covenant by means of various provisions of the Torah' ${ }^{20}$ The covenant, then, is the context within which we must understand Leviticus 18:5. ${ }^{21}$ In Leviticus 18:1-5, the three main parts of the covenantal formula are evident and, when investigated, they reveal the function of verse 5. Leviticus 18:2 provides the historical prologue of the covenantal formula, while Leviticus 18:3-4 state the covenantal stipulations. Leviticus 18:5 then offers the covenantal curses and blessings, with the emphasis firmly placed on the positive potentialthe potentially sublime outcome - of the covenant: 'you will keep my statutes and my ordinances; which by observing them a person will live'. Thus, Leviticus 18:5 offers forth the potential for which YHWH entered into the covenant with Israel, that they might live (i.e., that they might experience covenantal blessing). In sum, the significance of Leviticus 18:5 is best grasped when it is placed in its covenantal context. It has in view the purpose of the covenant, that is, the potential for unimaginable blessings that YHWH desires to pour out first on Israel and then through Israel on the world. ${ }^{22}$

19 Garlington, Role, 101, emphasis added.

20 Garlington, Role, 101.

21 Cf. J.D. Levenson, Sinai and Zion: An Entry into the Jewish Bible (New Voices in Biblical Studies; Minneapolis: Winston, 1985), 26-36, for a description of the six-step suzerainty covenantal formula. He has helpfully observed the importance of the covenantal formula for interpreting Israel's experience with God at mount Sinai. In a suzerain covenantal formula of the ancient Near East, there is a sequence of six steps characteristic of treaties between a suzerain (king) and vassal (petty monarch): (1) preamble or titulary; (2) historical prologue or antecedent history; (3) stipulations; (4) deposition; (5) list of witnesses; and (6) curses and blessings.

22 There is a debate concerning the nature of the life that is promised under the covenant. I agree with Garlington (Role, 103) who points out that the term must be qualified by its covenantal setting. He concludes, '... it is arguable that the life in question is not eschatological or eternal as such' (Garlington, Role, 103). Yet he acknowledges that certain strands of Jewish interpretation emphasise the eschatological dimension (cf. 1QS IV, 6-8; Dan. 12:2; 2 Macc. 7:9). On this basis it is evident that later inspired interpreters, wishing to preserve their authoritative scripture, adapted the traditions in light of their changing historical settings (R.P. Carroll, 'Prophecy and Dissonance: A Theoretical Approach to the Prophetic Tradition', ZAW 92 [1980] 108119); J.L. Kungel, 'Early Interpretation: The Common Background of Late Forms of Biblical Exegesis', in Early Biblical Interpretation, Vol. 3, ed. J.L. Kugel and R.A. Greer (Philadelphia: Westminster, 1986), 11-106; and G. Vermès, 'Bible and Midrash: Early Old Testament Exegesis', in The Cambridge History of the Bible, Vol. 1, ed. P.R. Ackroyd and C.F. Evans (Cambridge: CUP, 1970), 199-231. 


\subsection{Leviticus 18:5 in Ezekiel 20}

Ezekiel 20 is a theological-history of Israel's relationship with God and its purpose is to inventory Israel's continual failure to keep God's covenant; thus Ezekiel lays bear the root cause of God's coming judgment. Structurally, one can observe that chapter 20 is actually a microstructure of the entire prophecy. Like the book, it can be divided into two major divisions: Part one (20:1-31) addresses the unfaithful condition of the people ending in exile; and Part two (20:32-44) deals with YHWH's restoration and subsequent blessing of Israel in the future. The bottom line in this chapter is that while Israel's history has been one of rebellion, it will not ultimately end that way. God's purposes for Israel, which he established with Abraham, will be accomplished. According to Ezekiel, God is sovereign over the affairs of history and his plan will not be thwarted. In fact, from the language of this chapter, it seems that God, as the Sovereign Lord, even engineered the historical state of affairs for his own purpose. ${ }^{23}$

The reuse of the Leviticus 18:5 clause falls in the first part of the chapter where it appears three times ${ }^{24}(20: 11,13$, and 21) in what D.I. Block has labelled 'the second and third phases' of Ezekiel's retelling of Israel's history. ${ }^{25}$ These two sections seek to show the

23 Cf. Ezek. 20:25-26. Eslinger, 'Ezekiel 20 and the Metaphor of Historical Teleology: Concepts of Biblical History', JSOT 81 (1998) 108, likewise observes, 'Failure was part of the plan'.

24 In the MT they are virtually identical renderings of the clause (except a long form of the object marker $\square \int_{\tau}$ is in 20:11 and 21), but the LXX in 20:11 substitutes ö $\sigma \alpha$ for ö and adds $\alpha$ vó́s.

25 Cf. D.I. Block, The Book of Ezekiel Chapters 1-24 (NICOT; Grand Rapids: Eerdmans, 1997), 616-17. After a short preamble (vv. 1-4), Block organises the ch. around 7 eras or phases of history. 20:5-26 is divided into three phases of Israel's history: phase one describes Israel in Egypt (20:5-9); phase two describes the first generation of Israel in the desert (20:10-17) and phase three describes the second generation in the desert (20:18-26). The first two uses of the Lev. 18:5 clause appear in 'phase two'. The first use of Lev. 18:5 (20:11) corresponds to its original context in Lev. It describes the initial giving of the covenant stipulations that held the potential for on-going life under the covenant. The second is in (20:13)

$13 \mathrm{~b}$ But they did not walk in my commandments

$13 \mathrm{c}$ and they repelled my ordinances,

$13 \mathrm{~d}$ which by observing them, a man will live,

$13 \mathrm{e}$ and my Sabbaths they profaned exceedingly.

13f So I resolved to pour our my wrath upon them in the wilderness

$13 \mathrm{~g}$ in order to completely destroy them.

From Ezekiel's perspective, Israel, from the very beginning of its history, did not realise the potential that the clause represents. The statement, when taken in context, is actually one of the failure of potential because of the rebellion of the people. The result 
appropriateness of the coming judgment in light of Israel's wilful rebellion. Ezekiel's use of the Leviticus 18:5 clause in the retelling of the history of Israel - his inner-biblical exegesis - broadens and further develops the clause's significance beyond the Pentateuch. For Ezekiel, Leviticus 18:5 does not represent the positive purpose of the covenant, as it did in the Pentateuch, but now ironically, in light of Israel's history, it comes to signify the unrealised purpose of the covenant within redemptive history. Israel, therefore, could not say that it had experienced 'life' or the promises of the covenant. What they actually experienced was 'the curses' of the covenant - the negative potential of the covenant-thereby forfeiting God's divine intention for their existence. While the nation did continue in their unfaithful state in the historical period considered by Ezekiel, it was not due to 'the blessings' of the covenant, which would have been brought about by Israel's covenant faithfulness. God's mercy alone was the only basis for their continuance, and God's patience was about to run out as he swore to 'scatter them among the nations and disperse them to the lands’ (Ezek. 20:23).

\subsection{Leviticus 18:5 in Nehemiah 9:29 (2 Esdras 19:29)}

Nehemiah's use of the clause from Leviticus 18:5 is in line with what we observed in Ezekiel 20. ${ }^{26}$ However, Nehemiah makes explicit what was only implicit in Ezekiel. Nehemiah 9 contains another sweeping

of the covenantal failure was the experience of divine 'curses' (20:13f-g). All that stood between Israel and annihilation was God's grace as can be observed in 20:14. Israel as a whole was not erased, but the first generation of those delivered from Egypt was.

The third use of Lev. 18:5 appears in 20:21 in 'phase three':

21a But even their children rebelled against me,

$21 \mathrm{~b}$ they did not follow in my commandments

$21 \mathrm{c}$ and they did not keep my ordinances

$21 \mathrm{~d}$ in order to do them,

21e which by observing them, a person will live,

$21 \mathrm{f}$ and they profaned my Sabbaths.

In 20:18-19, God commands this new generation not to follow the manner of their fathers, and he reestablishes his covenant (the covenantal structure is recognizable: the preamble [19a]; and covenant stipulations/blessings and curses [19b-20]) and demands faithfulness. But again, instead of responsiveness, which would result in obedience, there is rebellion. And yet again, for a second generation, Israel fails to live out the potential within the covenant signified by Lev. 18:5.

26 For a discussion of the use of traditions in Neh. 9 and the identity of the author(s) of the canonical book of Nehemiah see M.J. Boda, Praying the Tradition: The Origin and Use of Tradition in Nehemiah 9 (BZAW 277; Berlin: de Gruyter, 1999). 
retelling of Israel's history. This time, however, it is not a pronouncement of judgment like in Ezekiel, but a confession of national sin. In his confession, Ezra characterises the people throughout its history, and even into his day, as stiff-necked, disobedient, and rebellious.

The historical context of verse 29 is in the late history of Israel prior to their exile. Ezekiel used the quotation in his second and third phases of history leaving the reader in the second generation of desert wanderers who did enter the land. While Ezekiel later shows the continuing unfaithfulness of Israel and their subsequent exile, the Nehemiah passage explicitly links the judgment of God with the failure of Israel, which resulted in the squandering of the potential (Lev. 18:5) of the covenant relationship. If it was not clear before, Ezekiel and Nehemiah show there was not a time prior to the exile when Israel lived out the positive purpose of Leviticus 18:5. According to Ezekiel and Nehemiah, throughout their history Israel remained under 'the curse' of the covenant and this ultimately resulted in their exile. In addition, Ezra's confession suggests that even within the initial stages of the return from Babylonian captivity, according to Nehemiah, Ezra continues to perceive that the nation remains under the covenantal curse awaiting redemption.

\subsection{Leviticus 18:5 in CD III, 16 (Damascus Document) ${ }^{27}$}

The Damascus Document (CD) has been recognised as one of the DSS community's foundational works. ${ }^{28}$ Among its varied contents is a theological history of the community's founding. In describing its history, the community closely connected its existence with that of biblical Israel. S. Talmon points out that the DSS community 'while in reality ... [it] existed in the Hellenistic and early Roman period, conceptually ... lived in the biblical age ...'29 The community assumes the role that the postexilic biblical historians (Ezra-Neh., 2 Chron. 36:22-23) and prophets (Haggai, Zechariah, and Malachi) accorded to the returnees from the Babylonian Exile in the early Persian Period ...

27 The Lev. 18:5 clause also appears in 4Q266 Frg. 11, 11b-12 and 4Q504 Frg. 6, 1618 but will not be dealt with here.

28 J.M. Baumgarten, 'Damascus Document', in EDSS 1, ed. L.H. Schiffman and J.C. VanderKam (Oxford: OUP, 2000), 166-70.

29 S. Talmon, 'Waiting for the Messiah: The Spiritual Universe of the Qumran Covenanters', in Judaisms and Their Messiahs at the Turn of the Christian Era, ed. J. Neusner, W.S. Green, and E.S. Frerichs (Cambridge: CUP, 1987), 117. 
'thus linking their own generation 'directly' to the post-destruction generation ...'30

The Damascus Document (CD I, 3-7), in recounting the establishment of the community, states that God had delivered the remnant out of exile and had planted them in the land. In their recounting of their history they, like Ezekiel and Nehemiah, emphasise the continual failure of Israel to keep the covenant (CD II, 14b-III, 12a) up through to the founding of the community. ${ }^{31}$ Like Ezekiel as well, the community lays out Israel's history in phases. In summarising Israel's history from Moses down to the exile, the Damascus Document (CD III, 10b-12a) states, 'Through it, the very first to enter the covenant made themselves guilty and were delivered up to the sword, for having deserted God's covenant and having chosen their whims, and having followed the stubbornness of their heart, each one doing (what was) his desire'. ${ }^{32}$ However, in the founding of the DSS community there is a dramatic reversal of this pattern of covenantal failure. The community takes up the theme of God's reestablishment of covenant with Israel (CD III, 12b-IV, 12a) and it is in this positive context we find an allusion to Leviticus 18:5. ${ }^{33}$

The DSS community believed themselves to be members of the eschatological remnant. They believed the eschaton was inaugurated and they interpreted the formation of the community as a proleptic experience of eschatological salvation. The clause from Leviticus 18:5 represented the realisation of the potential that was never realised in the past. It was only now, after the inauguration of the eschaton in the dawning of the restoration of Israel, that Israel could fulfil its

30 Talmon, Waiting, 117.

31 M.A. Knibb, The Qumran Community (Cambridge Commentaries on Writings of the Jewish and Christian World, $200 \mathrm{BC}$ to AD 200, vol. 2; Cambridge: CUP, 1987), $28-32$.

32 All quotations taken from F. García Martínez and E.J.C. Tigchelaar, The Dead Sea Scrolls Study Edition (Leiden: Brill, 1997), emphasis added.

33 Knibb, Qumran, 33; CD III, 12b-16 reads:

12b. Blank But with those who remained steadfast in God's precepts,

13. with those who were left from among them, God established his covenant with Israel for ever, revealing to them

14. hidden matters in which all Israel had gone astray: Blank his holy sabbaths and his

15. glorious feasts, his just stipulations and his truthful paths, and the wishes of his will which

16. man must do in order to live by them. Blank He disclosed (these matters) to them and they dug a well of plentiful water. 
covenantal potential. This is a different, yet complementary use of the expanded Leviticus 18:5 clause. Ezekiel and Nehemiah used the clause to express the negative side of the eschatological situation-the unrealised potential, while Qumran used the clause to express the positive side - the realisation of the covenant potential. Thus, later Jewish interpreters, both inside and outside the canon, have utilised the clause to signify both the pre- and post-restoration condition of Israel.

Summarizing the Jewish evidence: Ezekiel and Nehemiah through their 'inner-biblical' exegesis developed the Leviticus 18:5 clause, thereby infusing it with an expanded significance. The clause no longer simply designates the covenant potential as in the Pentateuch, rather, Ezekiel/Nehemiah, in their retelling of Israel's history, utilise the clause to express the unrealised covenant potential: the state of affairs prior and into the exile whereby Israel, because of its stiff-necked and stubborn condition, failed to fulfil the divine potential for which YHWH had chosen it. As a result it was judged, falling under 'the curse' of the covenant and was now awaiting its future restoration. However, its state as one exiled for unfaithfulness would be replaced by a new state brought about by the enactment of a new creation or new covenant (Ezek. 36) ${ }^{34}$ Consequently, Ezekiel and Nehemiah have given the clause an eschatological connotation. They convert it into a negative category, which describes the pre-restoration period: the time leading up to and including the exile. This Exile-Restoration connotation of Leviticus 18:5 is also utilised by the DSS community, although in the converse way. The DSS community, in light of their inaugurated eschatology and in contrast to Israel prior to the dawning of restoration, is now, as God's eschatological remnant, realising the covenantal potential.

This eschatological development in the interpretative tradition has been lost on nearly every commentator of the book of Galatians since

34 Cf. Jer. 31. While not in the scope of this paper it is important to note the complementary relationship Ezek. 20 and 36 share. The terms and concepts used in these two passages show their interrelatedness (ordinances, commandments, dwelling in the land, doing, observing, walking in God's ways, knowledge of God among the nations). The significance of this to my mind is that these two passages are mutually interpretative. For example, if Israel's root problem was not completely clear in ch. 20, 36:26 reveals that the root problem - the cause of the unfaithful state-was an absence of God's presence (i.e., the Spirit) and a hard heart. The prophets predicted a day when God would pour out His Spirit on Israel in order that they might realise their full potential within the covenant. This potential, which is summed up in the Lev. 18:5 quotation, was never realised in its history. 
they have only focused on the Leviticus 18:5 clause as it appears in the Pentateuch. Therefore, interpreters have not considered it in the interpretation of Galatians 3:12. It is to this interpretation we now turn.

\section{The Use of Leviticus 18:5 in Galatians 3:12 in Light of Later Jewish Scriptural Interpretation}

Thus far this essay has highlighted the lacuna in the three dominant interpretative approaches to Galatians 3:12. Moreover, an attempt has been made to understand the reuse of Leviticus 18:5 in later Jewish interpretation - both in and out of the canon. It has been asserted that when the clause from Leviticus 18:5 is read against the backdrop of its reinterpretation, the significance of the clause is expanded. In light of the preceding evidence, this section will suggest a possible reading of Galatians 3:12 within the redemptive historical framework of Exile and Restoration.

Galatians 3:12 falls into a discrete paragraph that begins with the conjunction yó $\rho$ in verse 10 and ends in verse 14 with two purpose statements (ivo clauses) that probably concluded not only this specific paragraph, but also the larger section of verses 1-14. The argument of the section can be divided into two main parts with the statements (rhetorical questions) of verses 1-5 further supported in verses 6-14 with two mini-arguments. The first $(3: 6-9)$ is introduced with $\kappa \alpha \theta \omega \varsigma s$ comparing Abraham's experience of justification with that of the Galatian believers'. ${ }^{35}$ With such a beginning Paul has powerfully supported the argument with a positive affirmation of the centrality of faith as the means for the reception of the Spirit. ${ }^{36}$

35 There is an assumed, but unfinished comparison in 3:6, 'Just as Abraham believed God, and it was credited to him for righteousness in the past, so those who depend on God now in the present, it is credited to them for righteousness'. This is the case because 3:7 immediately draws an inference (öpo) that assumes a comparison between Abraham and the Galatian believers in 3:6. The inference does not make sense without this assumed comparison. The translators of the ESV obviously recognise this problem and decide, instead, to take the clause with the previous question in $3: 5 \mathrm{~b},{ }^{\prime} \ldots$ or by hearing with faith-just as Abraham "believed God, and it was counted to him as righteousness"?'

36 The purpose of this comparison is seen in the inferences that Paul draws; first in verse 7 and then in verse 9. At issue here, is the reception of the blessing of Abraham by the Gentiles; this blessing of Abraham, as defined by Paul, is the Spirit $(3: 2-3 ; 14$; note the parallel iv $\alpha$ clauses). Moreover, the reception of the Spirit, he argues, is the consequence of becoming a son of Abraham through justification. Moreover the justification and thus the blessing is the result of faith. This first mini-argument can be 
The second mini-argument $(3: 10-14)^{37}$ is introduced with the conjunction róp. ${ }^{38}$ The logical relationships between the propositions in 3:10-12 can be laid out as follows:

10a Moreover ( $\gamma$ áp) everyone who is of the works of the Law is under a curse.

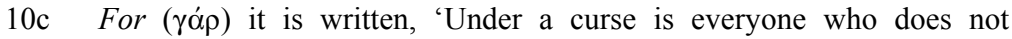
persevere in everything, which is written in the book of the Law, to do it'.

11a That is to say, ( $\delta \dot{\varepsilon})$ it is evident that in the law no one is made righteous before God

$11 \mathrm{~b}$ because (ö $\tau)$ 'the righteous will live out of ('亡) faith'

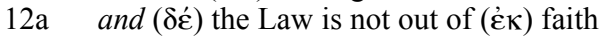

$12 \mathrm{~b}$ but the Law is from ( $\alpha \lambda \lambda$ ') 'the one who does these things will live by them'.

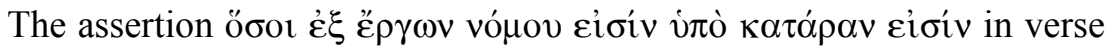
10a is supported ( $\gamma \alpha \dot{\alpha} \rho)$ by quotation from Scripture (portions of Deut.; cf. below) in verse $10 \mathrm{~b}$ and then restated for clarification in verses 1112 with four more propositions (3:11a; 11b; 12a; and 12b).

In this way, verses $11-12$ support verse 10 and are subordinate. ${ }^{39}$ 3:11a's proposition, which argues for the obvious fact that no one is made righteous before God in the law, is then supported by-or grounded on (ö $\tau$ ) - the propositions in $11 \mathrm{~b}$ and 12.

Galatians 3:12's two propositions form one statement. Paul's point in this complex statement is to designate from what or better from where 'the law' derives: from 'faith' or from 'the one who does these things will live by them'. With the two propositions, Paul utilises a contrast between negative and positive; he negates the first statement in order to emphasise the second. The negative proposition of 3:12a, 'the law is not from faith', is subordinate to and supportive of the positive proposition of $3: 12 \mathrm{~b}$, 'the law is from ...' Paul states that the law is from the 'thing' that is represented or implied by the Leviticus 18:5 clause ('the one who does these things will live by them').

summarised as follows: Faith (dependence on God) -leads to-Justification and Sonship (3:6-7) — which leads to- the Blessing of the Spirit (3:8-9).

37 I will not be analyzing 3:13-14 in any detail in this discussion.

38 The $\gamma \alpha$ ó here is not functioning with its normal force of 'confirmation'. Rather, 'it facilitates a connection which carries the argument forward' (Scott, Curse, 187). For a discussion of this use see DBAG, 189. For this use elsewhere in the NT see Rom. 12:3; 14:5; 1 Cor. $10: 1 ; 2$ Cor. $1: 12 ; 10: 12 ; 11: 5$; Gal. $1: 11 ; 5: 13$.

39 Cosgrove (Cross, 54) has pointed out the grammatical significance of the

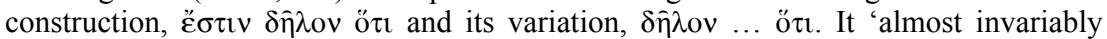
takes up or completes a preceding idea. Very rarely does a speaker use this expression to introduce a new thought or additional argument'. Cf. also Lightfoot, Galatians, 138. 
Note that Paul contrasts the term 'faith' with the Leviticus 18:5 clause. When one reads the clause from the standpoint of later interpretative tradition, the entire clause may be taken as a conceptual unit, which signifies the period of history characterised by the unrealised covenant potential. In other words, it is plausible that the clause should be taken as a conceptual whole designating the prerestoration condition of Israel.

Read this way, the contrast between 'faith' and 'law' implied in $3: 11 \mathrm{~b}$ and 12 is not between two mutually exclusive bases for righteousness (law/gospel antithesis), or two contradictory statements in the scripture (apocalyptic fulfilment), but between historical periods in salvation history: the period of unrealised covenant potential $(3: 12)$ and the period of realised covenant potential (3:11b). In other words, to be related to the Sinai covenant is to be related to the age (or historical period) of unfaithfulness and judgment (covenantal curse). On the other hand, being related to the new eschaton signified in the term $\pi i \sigma \tau \iota s$ (3:23) means being related to the age of faithfulness and blessing (covenantal promise) through Christ's redemption. With Habakkuk 2:4, Paul announces the new redemptive historical position where the righteous person now stands. Hence, Cosgrove is correct in drawing out the eschatological significance of Habakkuk 2:4 and the faith it describes. ${ }^{40}$ Read in the context of Galatians, 'faith is conceived of here as an eschatological reality, which enters the world with God's action in Christ' ${ }^{41}$ Paul subsumes this entire eschatological idea in verse $11 \mathrm{~b}$ into the term $\pi$ i $\sigma \tau \iota \varsigma$ in verse $12 \mathrm{a}$ and contrasts it with the clause from Leviticus 18:5. A paraphrase that interprets the statement with its full force could be:

12a Eschatologically speaking the Sinai covenant ${ }^{42}$ (= law) does not derive out of the age of realised covenantal potential (= faith),

40 Cf. Cosgrove (Cross, 52-57) argues that Hab. 2:4 'enjoyed widespread recognition in the early church as a prophecy of the coming faith (of Jesus Christ) by which the just would live'. Paul read this 'prophetic text eschatologically'. In other words, 'Hab 2:4 speaks of a time of fulfilment now arrived with Jesus Christ' (emphasis added). He finds support for this understanding in the use of 'faith' later in Gal. 3:23-26, where Paul speaks of faith 'coming' and 'being revealed' (Cosgrove, Cross, 56).

41 Cosgrove, Cross, 56, emphasis added.

42 It is recognised that 'law' here is a synecdoche signifying the whole Sinai covenant. Cf. Hafemann (Exile, 342) who observes this in the phrase 'under law' in $3: 23$ and 4:5. 'Hence, Israel's being "held in custody by the Law" is descriptive of her particular experience in the pre-redemptive period (i.e. the period of the Sinai covenant) ...' 
$12 \mathrm{~b}$ but it derives out of the age of Israel's unrealised covenantal potential (= 'the one who does them will live by them').

The point of $3: 11 \mathrm{a}$ is so obvious for Paul—and should be for his readers-because, first, the age of realised covenantal potential has arrived in the atoning death and resurrection of Christ (3:11b); and secondly, the law was born and remains biologically linked to the age of unrealised covenantal potential (3:12) ${ }^{43}$

In Paul's argument, this eschatological statement in 3:11-12 logically clarifies the statement of 3:10. Both Scott and Wright independently have demonstrated that Paul's use of Deuteronomy in Galatians 3:10 reveals the covenantal basis of Paul's argument from 3:10-14. The combination of Deuteronomy 27:26 with Deuteronomy $29: 19 \mathrm{~b}$ (or 28:58) together with the formulaic expression of

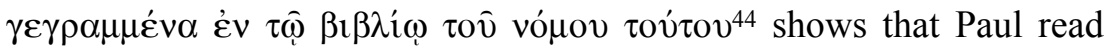
Deuteronomy $27-32$ as a unit. ${ }^{45}$ Scott argues that 'Paul's own argument $\ldots$ is bound together by the contrast between "curse" (3:10a, 13a) and "blessing" (3:14a; cf. 3:9)' which seems most likely taken from the Blessings and Curses theme of this section of Deuteronomy. ${ }^{46}$ Further Scott contends that Paul in 3:10, drawing on the Jewish tradition of second temple Judaism of an extended exile, 'assumes here that the

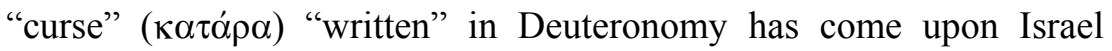
because of national sin, and that ... it continued to abide on the people to his day'. ${ }^{47}$ Though there has been an increasing number of recent arguments against this view, I remain convinced that it is generally the most persuasive hypothesis explaining the structure and background of Galatians 3:10-14. ${ }^{48}$

43 See similarly Gal. 4:21-31 where Paul connects the Sinai covenant with the Jerusalem of his time and places it in contrast to the new covenant connected to the Jerusalem from above. In this context Jerusalem is used to represent the two redemptive historical eras; cf. J. Willitts, 'Heilsgeschichte in Galatians: The Use of Isaiah 54:1 in Galatians 4:21-27: A Response to J. Louis Martyn' (Dallas Theological Seminary, August 2000).

44 Cf. Deut. 28:58, 61; 29:19, 20, 26; 30:10.

45 Scott, Curse, 194.

46 Scott, Curse, 195; cf. also Wright, Climax, 137-56.

47 Scott, Curse, 214. Scott and Wright differ on whether Paul is applying the curse to 'national' Israel or a more 'individualized and generalized' application of the curse due to the presence of öбor (Wright, Climax, 191, 147).

48 For recent critiques of the view see Bryan, Jesus, 12ff.; Kim, Paul, 136-41; and B.W. Longenecker, The Triumph of Abraham's God: The Transformation of Identity in Galatians (Edinburgh: T\&T Clark, 1998), 137-42. I will not attempt to defend the Exile-Restoration scheme here. However, the view is often criticised because it lacks a 
Paul's point is that under the Sinai covenant Israel failed to keep the stipulations and consequently fell under the Deuteronomic curses. These curses remained, in Paul's view, until the coming of Christ and his atonement for sin was accomplished. This point is further clarified in 3:11-12 by the eschatological contrast signalled in the term $\pi i \sigma \tau i \varsigma^{49}$ as it signifies the age of realised covenant potential and the clause of Leviticus $18: 5$ as it signifies the age of unrealised potential. The turning of the ages has come in Christ's work of redemption. Therefore, the Sinai covenant, which was made weak by its redemptive-historical position and, thus, was always only a symbol of the substance that was to come in the new covenant, has been superseded; it served its purpose (3:19-29; cf. Heb. 10:1-4, 11). Participation in the eschatological age of faith with its resulting justification brings about the realisation of covenantal blessing. This second mini-argument, with its redemptive-historical structure, can be summarised as follows:

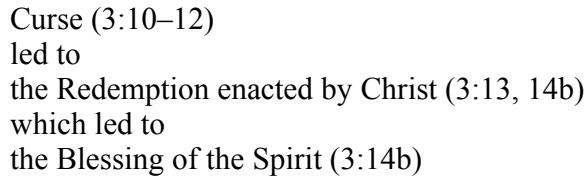

With the two mini-arguments of 3:6-9 and 3:10-14, Paul has supported the statements he made in 3:1-5. The ongoing experience of the presence of the Spirit in the lives of believers does not result from putting oneself back under the Sinai covenant, because the blessing of the Spirit is received by means of faith (3:6-9), and because the blessing of the Spirit is the consequence of the inaugurated new age of salvation in Christ (3:10-14).

more careful nuancing of the issues. Several scholars are uncomfortable with the term 'exile', but would agree with the idea of an incomplete or non-restoration state of affairs in the first century. We must be careful not to throw out the baby with the bath water. Though the term 'exile' may be a stumbling block to some, the ideology that this scheme represents is correct.

49 Cosgrove (Cross, 55) observes that the term 'faith' which is the primary idea of Hab. 2:4, 'was the characteristic term used by early Christians in speaking about the reception of the gospel and it also served as metonymy for the gospel itself' (emphasis added). 


\section{Conclusion}

In this article it has been argued that Leviticus 18:5 should be considered against the broader context of later Jewish interpretative tradition. When this is done, one observes that the clause takes on a wider significance than the one found in the Pentateuch. Ezekiel and Nehemiah place the clause in the context of Israel's failure to maintain its covenant with YHWH. In so doing, the Leviticus 18:5 clause, instead of signifying the positive purpose of the covenant as it did in Leviticus, ironically comes to represent the unrealised covenant potential. For Ezekiel and Nehemiah, it is an expression for the era of Israel's covenantal failure. The eschatological connotation of the clause was also found outside the Hebrew canon in its reuse in the Damascus Document of the DSS.

What is more, it was asserted that Paul might have read the citation from Leviticus 18:5 in a way concordant with this later interpretative tradition. Whether he depended on the tradition or interpreted Leviticus 18:5 independently cannot be determined with certainty. However it seems probable that Paul would have been familiar with the texts of Ezekiel and Nehemiah. Based on this working hypothesis, a fresh reading of Galatians 3:12 was offered within a redemptive historical/Exile-Restoration framework. This reading argued that the clause, read as a conceptual unit, was contrasted with the term $\pi i \sigma \tau \iota \zeta$, which made a historical contrast between the age of realised covenant potential and the age of unrealised potential. If the reading has any merit, then it has the capacity not only further to substantiate but also to refine redemptive-historical interpretative framework. I hope this thesis, at the very least, causes interpreters of Galatians 3:10-14whatever their interpretative stripe - to take into account the later Jewish scriptural interpretation of Leviticus 18:5. 